\title{
Usefulness of pre- and post-transplant BK virus-specific ELISPOT assay for predicting the outcome of BK virus infection in kidney transplant recipients
}

\author{
Eun Jeong Ko ${ }^{1}$, Hyunjoon Bae ${ }^{2}$, Ki Hyun Park ${ }^{2}$, Chul Woo Yang ${ }^{1}$, Byung Ha Chung ${ }^{1}$, Eun-Jee $\mathrm{Oh}^{2}$ \\ ${ }^{1}$ Division of Nephrology, Department of Internal Medicine, Seoul St. Mary's Hospital, College of Medicine, The Catholic University of Korea, Seoul, Korea \\ ${ }^{2}$ Department of Laboratory Medicine, Seoul St. Mary's Hospital, College of Medicine, The Catholic University of Korea, Seoul, Korea
}

Background: To investigate if BK virus (BKV)-specific T cell immunity measured by an interferon- $\gamma$ enzyme-linked immunospot (ELISPOT) assay at pre- and post-transplant can predict the outcome of BKV infection in kidney transplant recipients (KTRs). Methods: We included $60 \mathrm{KTRs}$ with BK viremia and checked BKV ELISPOT assay at pre- and post-transplant 1 month, 3 months, and the time of BKV viremia detected. All participants were divided into persistent-viremia group ( $>3$ months) and cleared-viremia group ( $<3$ months) according to sustained duration of BKV infection. We compared pre- and post-transplant BKV-ELISPOT results against five BKV peptide mixes (LT, St, VP1-3), and fluorescence-activated cell sorting (FACS) of immune cell results.

Results: The pre-transplant BKV-ELISPOT results were lower in persistent-viremia group than those of cleared-viremia group $(P=0.054)$. Also, they tends to be lower in $B K V$-associated nephropathy (BKVN) group compared to those of No-BKVN group $(P=0.133)$. At the time of the first BK viremia detected, BKVN group had tendency of lower St, VP1-ELISPOT results compared to No-BKVN group $(P=0.075, P=0.071$, respectively). In FACS analysis at the time of viremia, persistent-viremia group showed higher portion of CD8+ T cell, and CD3+CD4+CD57+CD28nullCD161+ cell compared to cleared-viremia group $(P=0.014, P=0.019$, respectively).

Conclusions: Pre- and post-transplant BKV-ELISPOT assay may be effective in predicting clinical outcomes of BKV infection in terms of clearance of BKV and development of BKVN.

Corresponding author: Eun Jeong Ko

E-mail: neat0505@gmail.com

(c) The Korean Society for Transplantation

This is an Open Access article distributed under the terms of the Creative Commons Attribution Non-Commercial License (http://creativecommons.org/licenses/by-nc/4.0/) which permits unrestricted non-commercial use, distribution, and reproduction in any medium, provided the original work is properly cited. 